\title{
Hindcasting the continuum of Dansgaard-Oeschger variability: mechanisms, patterns and timing
}

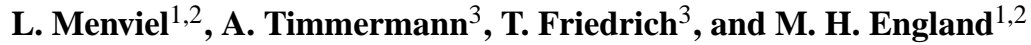 \\ ${ }^{1}$ Climate Change Research Centre, University of New South Wales, Sydney, Australia \\ ${ }^{2}$ ARC Centre of Excellence in Climate System Science, Australia \\ ${ }^{3}$ International Pacific Research Center, University of Hawaii, Honolulu, USA
}

Correspondence to: L. Menviel (1.menviel@unsw.edu.au)

Received: 26 July 2013 - Published in Clim. Past Discuss.: 16 August 2013

Revised: 14 November 2013 - Accepted: 5 December 2013 - Published: 14 January 2014

\begin{abstract}
Millennial-scale variability associated with Dansgaard-Oeschger events is arguably one of the most puzzling climate phenomena ever discovered in paleoclimate archives. Here, we set out to elucidate the underlying dynamics by conducting a transient global hindcast simulation with a 3-D intermediate complexity earth system model covering the period 50 to $30 \mathrm{kaBP}$. The model is forced by time-varying external boundary conditions (greenhouse gases, orbital forcing, and ice-sheet orography and albedo) and anomalous North Atlantic freshwater fluxes, which mimic the effects of changing northern hemispheric ice volume on millennial timescales. Together these forcings generate a realistic global climate trajectory, as demonstrated by an extensive model/paleo data comparison. Our results are consistent with the idea that variations in ice-sheet calving and subsequent changes of the Atlantic Meridional Overturning Circulation were the main drivers for the continuum of glacial millennial-scale variability seen in paleorecords across the globe.
\end{abstract}

\section{Introduction}

The glacial climate system during Marine Isotope Stage 3 (MIS3, 59.4-27.8 ka BP) experienced massive variability on timescales of centuries to millennia (Masson-Delmotte et al., 2013), referred to as Dansgaard-Oeschger (DO) variability. DO events are characterized by rapid northern hemispheric transitions from cold (stadial) to warm (interstadial) conditions (Fig. 1, black line), subsequent gradual cooling and final rapid transitions to cold conditions (Dansgaard et al., 1993). The origin of this prominent variability still remains elusive with proposed mechanisms invoking internal ocean-sea-ice climate instabilities (Timmermann et al., 2003; Dokken et al., 2013), coupled synchronized oceanice-sheet variability (Schulz et al., 2002), North Atlantic sea ice (Li et al., 2005, 2010) and sea-ice-ice-shelf fluctuations (Petersen et al., 2013) as well as externally solar-driven reorganizations of the ocean circulation (Braun et al., 2008).

An important element of DO events is the corresponding variability of ice-rafted debris (an indicator for iceberg surges) (Bond and Lotti, 1995; Sarnthein et al., 2001), illustrated here in a high-resolution ice-rafted debris (IRD) composite record from the Irminger and Iceland seas cores SO825 (van Kreveld et al., 2000) and PS2644 (Voelker et al., 2000) (Fig. 1, upper panel, orange line). We observe that within the age uncertainties, all DO stadials between 30-50 ka BP were accompanied by iceberg surges, which originated from the adjacent northern hemispheric ice sheets. According to these marine records and other data sets from the northern North Atlantic (e.g., Elliot et al., 1998; Grousset et al., 2001; Elliot et al., 2002), the iceberg calving increased during interstadial periods and peaked at the end of the stadials, after which it decayed rapidly. This sequence of events is consistent with the notion of a freshwater-driven throttling of oceanic convection (Sarnthein et al., 2001), meridional mass and heat transport and subsequent sea-ice expansion, which caused the gradual cooling during interstadials. Moreover, possible feedbacks between the Atlantic meridional overturning circulation (AMOC) and ice sheets may have further modulated the evolution of iceberg and freshwater discharges into the North Atlantic as previously suggested (Schulz et al., 2002; 


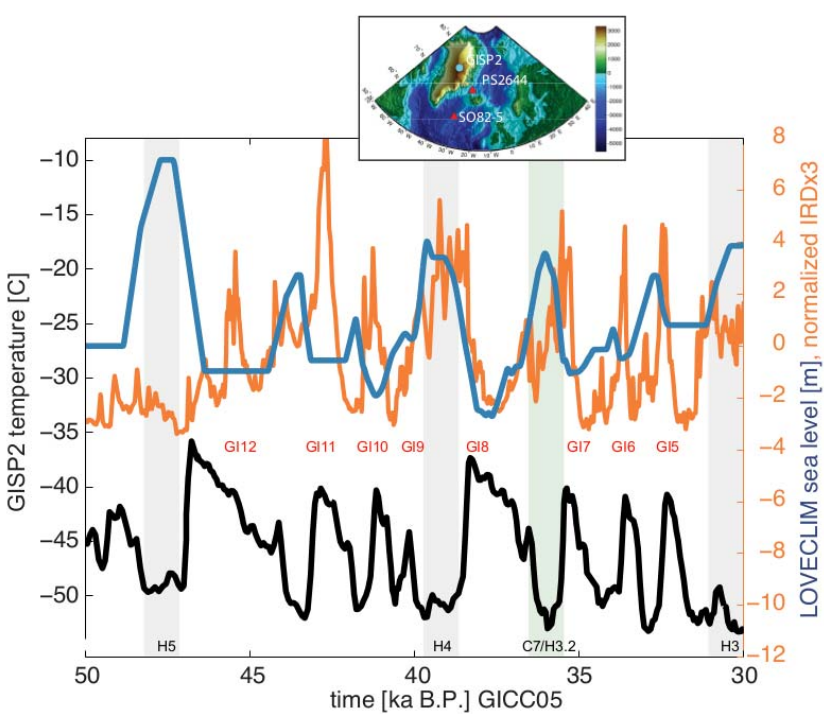

Fig. 1. Upper panel: composite IRD record (orange) obtained from the average of the normalized IRD records of SO82-5 (van Kreveld et al., 2000) and PS2644 (Voelker et al., 2000) from the northern North Atlantic (see map inlay). Integral of freshwater flux forcing used in the LOVECLIM MIS3 hindcast simulation (blue) (see Fig. 2, upper panel). Lower panel: GISP2 reconstructed central Greenland temperatures (Alley, 2000). Greenland interstadials (GI) are highlighted by red labels. The main Heinrich events are represented by gray bars and the light green bar marks are the Greenland stadial C7 just prior to GI7. The age shift between the GISP2 record (Alley, 2000) and the NGRIP record on the GICC05 timescale (Andersen et al., 2006; Svensson et al., 2006) is determined. To project the paleorecords onto the common GICC05 age model, we apply this shift to the GISP2 record and to IRD records of cores SO82-5 and PS2644, whose original age models were partly based on correlations with GISP2. Subsequently the IRD composite (orange) was calculated.

Timmermann et al., 2003; Shaffer et al., 2004; Alvarez-Solas et al., 2010; Marcott et al., 2011; Alvarez-Solas et al., 2013).

In addition to DO-related IRD variability, there is widespread sedimentary evidence (e.g Heinrich, 1988; Zahn et al., 1997; van Kreveld et al., 2000; Schönfeld et al., 2003; Hemming, 2004; Hodell et al., 2010) for massive iceberg surges that originated mainly from the Laurentide ice sheet and extended far into the eastern North Atlantic (e.g., Grousset et al., 1993). During these so-called Heinrich events a large amount of freshwater was released into the North Atlantic, causing a weakening of the AMOC, as suggested by paleoproxy data (Kissel et al., 2008; Sarnthein et al., 1995, 2001; Vidal et al., 1997; Zahn et al., 1997) and numerous climate modeling experiments (Stouffer et al., 2007; Krebs and Timmermann, 2007; Kageyama et al., 2013). Climate models further document that the corresponding changes in meridional oceanic heat transport, SST and atmospheric circulation are consistent with paleodata evidence of an interhemispheric temperature seesaw (e.g., Stenni et al., 2011),
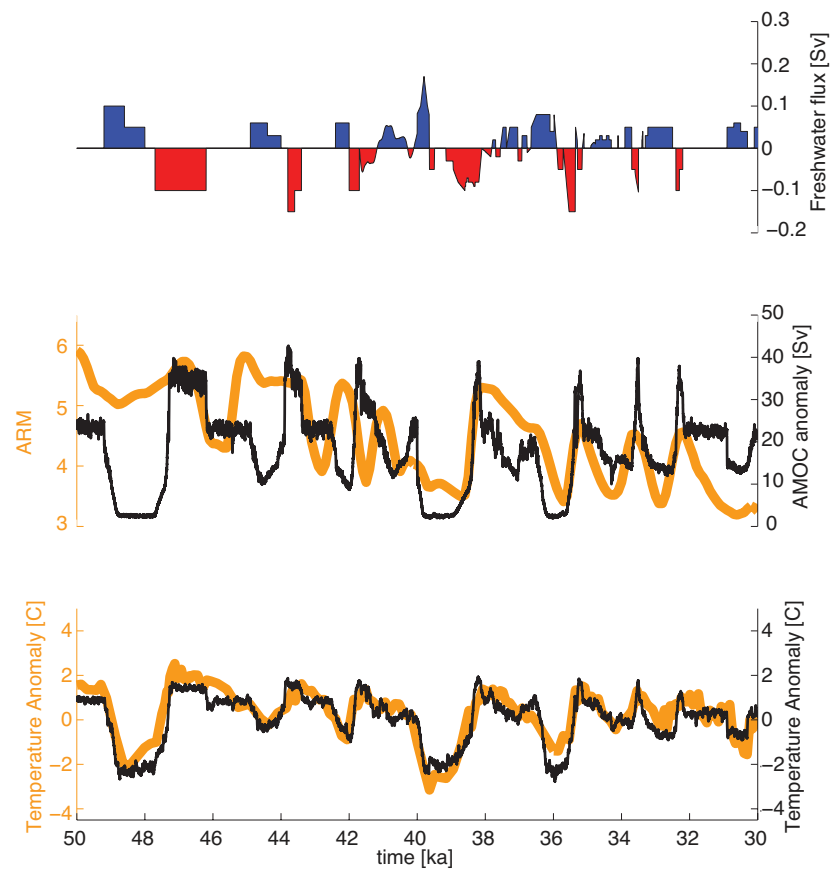

Fig. 2. From top to bottom: time series of North Atlantic freshwater forcing (Sv) applied to LOVECLIM in the region $55-10^{\circ} \mathrm{W}, 50-$ $65^{\circ} \mathrm{N}$; simulated maximum meridional overturning circulation in the North Atlantic (Sv) compared to North Atlantic marine sediment cores ARM data (Kissel et al., 2008); and simulated SST anomalies off the Iberian margin $\left(15-8^{\circ} \mathrm{W}, 37-43^{\circ} \mathrm{N}\right)$ compared to alkenone-based SST anomalies from marine sediment core MD012444 (Martrat et al., 2007). Model results are in black and paleoproxy records in orange.

large-scale drying of Eurasia (e.g., Harrison and SánchezGoñi, 2010) and the northern tropics (e.g., Wang et al., 2001; Deplazes et al., 2013) and increased precipitation in parts of the southern hemispheric tropics (Garcin et al., 2006; Wang et al., 2007; Kanner et al., 2013).

Based on their very distinctive sedimentological characteristics, Heinrich stadials (HS) have often been regarded as dynamically different from other DO stadial-interstadial transitions. However, given the fact that both Heinrich and DO stadials were accompanied by (i) large-scale oceanic changes (Fig. 2), (ii) IRD layers (Fig. 1) and (iii) similar global teleconnections, we hypothesize here that Heinrich and DO stadials are part of a continuum of variability that is generated through ice-sheet-driven AMOC changes.

In this paper we set out to simulate the time evolution of DO and Heinrich variability for the period 50-30 ka BP using an intermediate complexity global climate model. We will compare the simulated variability with high-resolution paleoclimate reconstructions. The model simulation is based on the underlying assumption that the continuum of MIS3 climate variability on centennial to millennial timescales can be generated by a suitable North Atlantic freshwater forcing and the associated AMOC response. 
The paper is organized as follows: in Sect. 2 the model and experimental setup are described. In Sect. 3 we discuss the patterns of variability associated with DO cycles, the abruptness of stadial-interstadial transitions as well as the timing of Heinrich stadials. We also derive a common age scale that allows for a better comparison between paleoproxy records and model simulations. The paper concludes with a synthesis and discussion of the main results.

\section{Model and experimental setup}

One of the key goals of our study is to simulate the sequence of millennial-scale events during the period 50$30 \mathrm{ka} \mathrm{BP}$ and to determine the corresponding global teleconnections. For this task we have chosen the intermediate complexity earth system model LOVECLIM (Timm and Timmermann, 2007; Menviel et al., 2008; Timmermann et al., 2009b; Goosse et al., 2010). The ocean component of LOVECLIM (CLIO) consists of a free-surface primitive equation model with a horizontal resolution of $3^{\circ}$ longitude, $3^{\circ}$ latitude, and 20 depth layers. The 3-D atmospheric component (ECBilt) is a spectral T21, three-level model based on quasigeostrophic equations of motion and ageostrophic corrections. LOVECLIM also includes a dynamic-thermodynamic sea-ice model, a land surface scheme, a dynamic global vegetation model (VECODE, Brovkin et al., 1997) and a marine carbon cycle model (LOCH, Menviel et al., 2008; Mouchet, 2011).

Initial conditions for the transient run were obtained by conducting an equilibrium spin-up simulation using an atmospheric $\mathrm{CO}_{2}$ content of 207.5 ppmv, orbital forcing for the time $50 \mathrm{kaBP}$ and an estimate of the $50 \mathrm{ka} \mathrm{BP}$ ice-sheet orography and albedo which were obtained from a $130 \mathrm{ka}$ off-line ice-sheet model simulation (Abe-Ouchi et al., 2007). In the subsequent transient run greenhouse gases, orbital and ice-sheet forcing were updated continuously following the methodology of Timm et al. (2008). Note that our coupled model does not include an interactive ice sheet. Therefore, freshwater withholding from the ocean during phases of icesheet growth and freshwater release into the ocean as a result of ice-sheet calving and ablation are not explicitly captured. To mimic the time evolution of these terms and their effect on the ocean circulation, we apply an anomalous North Atlantic freshwater forcing $F(t)$ to the North Atlantic region $55-10^{\circ} \mathrm{W}, 50-65^{\circ} \mathrm{N}$. Negative forcing anomalies can be interpreted as periods of ice-sheet growth and excess evaporation over precipitation, whereas positive freshwater anomalies represent times of negative net mass balance of the northern hemispheric ice sheet, associated for instance with massive iceberg calving events or surface ablation.

The freshwater forcing time series $F(t)$ is obtained through an iterative procedure, that optimizes the anomalous freshwater flux such that the simulated temperature anomalies $T_{\mathrm{S}}(t)$ in the eastern subtropical North Atlantic best match the target alkenone-based SST anomalies $T_{\mathrm{r}}(t)$ reconstructed from the Iberian margin core MD01-2443 (Martrat et al., 2007) (Fig. 2, lower panel, orange line). Starting from an initial guess of the freshwater forcing $F_{i}(t)=-\alpha T_{\mathrm{r}}(t)$, a series of about $j<5$ experiments was conducted every $1000 \mathrm{yr}$ using additional freshwater flux perturbations $\delta F^{(j)}(t)$. In each of these $1000 \mathrm{yr}$ long chunks, the freshwater forcing scenario (j) was selected with $F^{(j)}(t)=F_{i}(t)+\delta F^{(j)}(t)$ that minimized the cost function

$J^{(j)}(t)=\int_{t}^{t+\tau} \beta\left(T_{\mathrm{S}}\left(t^{\prime}\right)-T_{\mathrm{r}}\left(t^{\prime}\right)\right)^{2}+\gamma\left(\dot{T}_{\mathrm{S}}\left(t^{\prime}\right)-\dot{T}_{\mathrm{r}}\left(t^{\prime}\right)\right)^{2} \mathrm{~d} t^{\prime}$,

within this window $[t, t+\tau]$ with $\tau=1000 \mathrm{yr}$. The simulated temperature evolution for $T_{\mathrm{S}}\left(t^{\prime}\right)$ in the integral is a function of the applied freshwater forcing $F^{(j)}\left(t^{\prime}\right)$. The resulting concatenated freshwater forcing time series $F(t)$ is shown in Fig. 2 (upper panel). Similar to data-assimilation methods that adjust parameters and/or dynamical variables to reduce the mismatch between observations and models, $F(t)$ has the sole purpose to force LOVECLIM into a realistic trajectory with respect to millennial-scale subtropical North Atlantic SST anomalies during MIS3. We did not choose the Greenland temperature reconstruction as an optimization target, because it shows only very weak differences between DO and Heinrich stadials, in contrast to the North Atlantic SST reconstructions.

\section{Results}

\subsection{Freshwater forcing}

The applied North Atlantic freshwater forcing $F(t)$ captures the dominant meltwater pulses associated with Heinrich stadials (Fig. 2). It compares well with a recent freshwater forcing estimate (Jackson et al., 2010) obtained with a North Atlantic box model through Bayesian inversion methods $^{1}$. In both cases stadial-interstadial transitions are triggered by negative forcing anomalies, which increase North Atlantic surface densities and subsequently strengthen the AMOC (Fig. 2, middle panel). Negative freshwater forcing can be interpreted to represent a positive ice-sheet mass balance, which in our modeling framework mimics a reduction of the continental runoff as well as excess evaporation over precipitation over the North Atlantic region. As an independent validation of our freshwater forcing, we compare the time-integral of $F(t)$, which represents the corresponding global sea level changes, with the composite IRD records from the Nordic Seas cores PS2644 and SO82-5 (Fig. 1) on the GICC05 timescale (see Sect. 3.6 for more details on the

\footnotetext{
${ }^{1}$ Some discrepancies between $F(t)$ and the freshwater estimate of Jackson et al. (2010) arise from the different AMOC sensitivities to freshwater perturbations and the different choice of the optimization target (GISP2 for the box model Jackson et al., 2010 and Iberian margin SST for LOVECLIM)
} 
synchronization of the cores and the model results). The rationale of this comparison is that high values of IRD correspond to additional freshwater discharge and sea level rise. Furthermore, rising sea level can amplify iceberg calving through ice-shelf instabilities. Except for the simulated sea level rise associated with Heinrich event 5, which is not captured in these eastern North Atlantic paleorecords, we find a relatively good match between model simulation and reconstruction, thus supporting the realism of the applied freshwater forcing. It should be noted here that the simulated DOrelated sea level changes are a factor 2-3 smaller than those reconstructed from the Red Sea during this time (Siddall et al., 2003).

\subsection{AMOC response}

As a result of the applied anomalous North Atlantic freshwater fluxes, the AMOC weakens and strengthens on millennial timescales. Heinrich stadials correspond to a complete shutdown of the AMOC, whereas DO stadials are associated with a $50 \%$ weakening of the AMOC, relative to the interstadial periods (Fig. 2). The resulting AMOC time series compares reasonably well with a reconstruction of Atlantic bottom currents obtained from mass-normalized anhysteretic remanent magnetization (ARM) data (Kissel et al., 2008) (Fig. 2, middle panel), even though the model and paleoceanography time series are based on different underlying age models (a more detailed discussion of age-scale uncertainties is provided is Sect. 3.6).

\subsection{Temperature response}

The excellent agreement between simulated and reconstructed SST anomalies in the Iberian margin area (Fig. 2 lower panel) is to be expected, because the latter has been used as the target for the optimization of the freshwater fluxes. One important finding is that the temperature drop in the northeast Atlantic around $36 \mathrm{ka} \mathrm{BP}$ (referred to as C7, adopting the Chapman and Shackleton, 1999 terminology) can be obtained in our simulation only by a complete shutdown of the AMOC, which is induced by a prolonged freshwater flux of $\sim 0.1 \mathrm{~Sv}$. This is consistent with the presence of an IRD pulse in the Greenland and Irminger seas (see Fig. 1), a drop in sea-surface salinity in SO82-5 (van Kreveld et al., 2000) and changes in benthic $\delta^{18} \mathrm{O}$ (Margari et al., 2010). Whereas the IRD pulse is well pronounced in the composite IRD time series (Fig. 1), as well as in records from the Irminger basin (SU 90-24) (Elliot et al., 2002), the southern Gardar Drift (JPC-13) (Hodell et al., 2010) and from the Iberian margin (MD95-2040) (Schönfeld et al., 2003); it appears to be absent in other southwestern Atlantic IRD records (e.g., Grousset et al., 1993; Rashid et al., 2003; Nave et al., 2007).

We move on to a more detailed comparison with other temperature reconstructions from the North Atlantic and
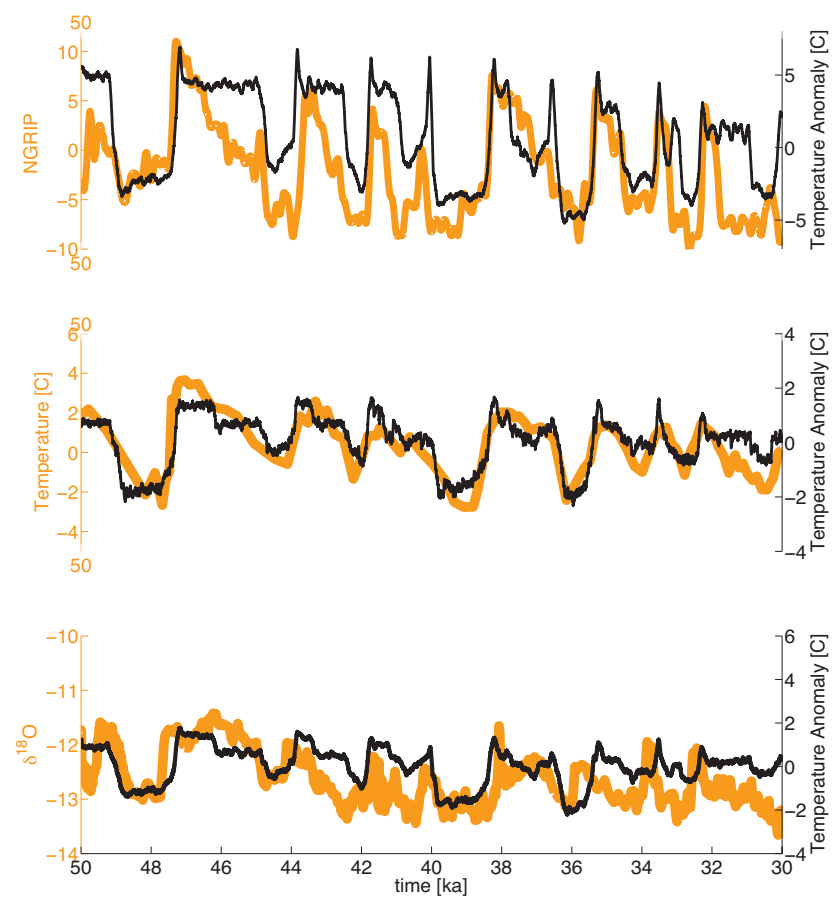

Fig. 3. From top to bottom: time series of simulated northeastern Greenland air temperature anomalies $\left(40^{\circ} \mathrm{W}-10^{\circ} \mathrm{E}, 66-85^{\circ} \mathrm{N}\right)$ compared to the NGRIP temperature reconstruction (Huber et al., 2006); simulated SST in the western Mediterranean compared to alkenone-based SST reconstructions from the Alboran Sea ODP hole 161-977A (Martrat et al., 2007) and simulated air temperature anomalies over Turkey $\left(25-46^{\circ} \mathrm{E}, 35-42^{\circ} \mathrm{N}\right)$ compared to a speleothem $\delta^{18} \mathrm{O}$ record (\%o) from Sofular Cave, Turkey (Fleitmann et al., 2009). Model results are in black and paleoproxy records in orange.

Mediterranean realm. Figure 3 shows the comparison between simulated surface temperatures in Greenland and NGRIP temperature reconstructions (Huber et al., 2006) on the SS09 timescale. In accordance with paleodata, the simulated Heinrich stadials in Greenland attain very similar minimum temperatures than the DO stadials. This behavior in Greenland is quite distinct from SST reconstructions (Fig. 2 lower panel and Fig. 3 middle panel), which exhibit a marked difference between Heinrich and non-Heinrich stadials. These results indicate the presence of a nonlinear seaice feedback (Li et al., 2005; Deplazes et al., 2013) which saturates when sea ice reaches a certain extent, thus capping cooling over Greenland. Simulated stadial-interstadial transitions attain values of about $9^{\circ} \mathrm{C}$ in Greenland, which is smaller than the reconstructed values of up to $16^{\circ} \mathrm{C}$ (Capron et al., 2010). Moreover, the simulation does not capture the slow interstadial cooling seen in the reconstructions. Instead interstadial periods have relatively constant Greenland temperatures in the model, except for an initial overshoot. These dynamics clearly differs from the behavior of SSTs in the northeastern Atlantic/Mediterranean (Figs. 2 and 3), which 

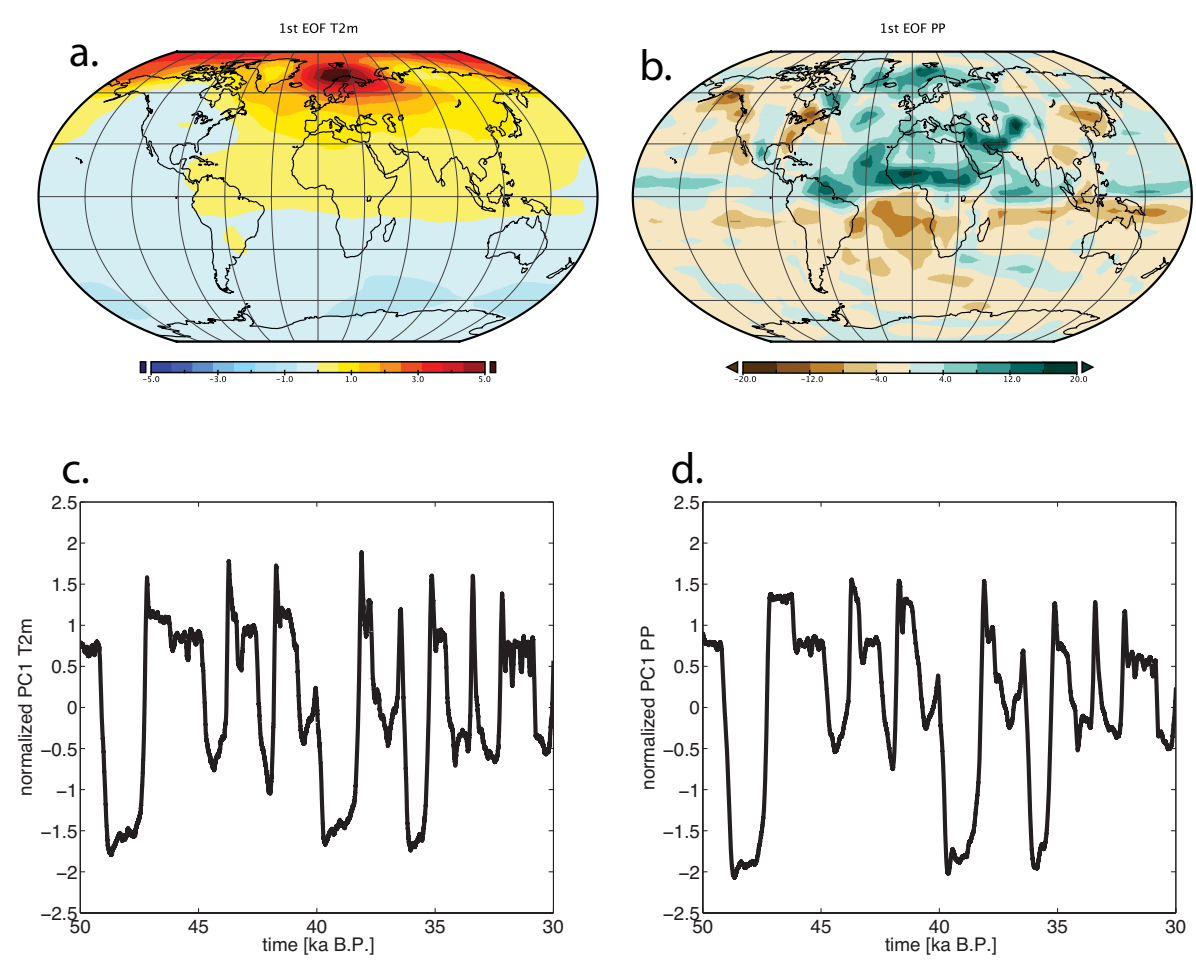

Fig. 4. (a) Pattern of first EOF of detrended $2 \mathrm{~m}$ air temperature anomalies $\left({ }^{\circ} \mathrm{C}\right)$; (b) pattern of first EOF of detrended precipitation anomalies $\left(\mathrm{cm} \mathrm{yr}^{-1}\right)$; (c) normalized principal component of 1 st EOF of detrended $2 \mathrm{~m}$ air temperature, which explains $64 \%$ of the variance; (d) normalized principal component of 1 st EOF of detrended precipitation, which explains $16 \%$ of the variance.

tracks the underlying AMOC variability much more accurately. Moving further into the eastern Mediterranean region, we find a reasonable qualitative match between the simulated temperature anomalies in Turkey and the $\delta^{18} \mathrm{O}$ record from independently dated speleothems from Sofular Cave (Fleitmann et al., 2009), which capture a combined temperature/hydroclimate signal.

A more comprehensive spatial view of the simulated DO/Heinrich dynamics is obtained from an EOF analysis of global surface air temperatures (Fig. 4a). The dominant EOF mode is characterized by a meridional temperature seesaw in accordance with numerous other modeling studies (Stouffer et al., 2006, 2007; Timmermann et al., 2009a; Kageyama et al., 2013) and paleoclimate data sets (Blunier et al., 1998; Barker et al., 2009; Stenni et al., 2011). Interstadial conditions are characterized by northern hemispheric warming with strongest amplitudes over the Greenland, Iceland, and Norway seas and the Arctic Ocean. The warming extends into North Africa, Asia and the western North Pacific. This warming pattern is in general agreement with pollenderived temperature reconstructions for GI8 (38 ka BP) and GI6 (33 ka BP) (Harrison and Sánchez-Goñi, 2010). The corresponding principal component time series (Fig. 4c) clearly features the enhanced cooling during massive Heinrich stadials (HS5 and HS4) and the C7 stadial, in contrast to the weaker cooling associated with DO stadials. Simulated southern hemispheric cooling during interstadials is consistent with the presence of a bipolar temperature seesaw (Stocker, 1998; Stocker and Johnsen, 2003).

\subsection{Hydroclimate response}

As a result of the very strong North Atlantic cooling during Heinrich stadials (HS5, HS4) and during the C7 stadial (Fig. 3), northern hemispheric trade winds intensify by up to $60 \%$, which leads to a southward shift of the Intertropical Convergence Zones, extending from South America, into the tropical Atlantic, equatorial Africa and the Indian Ocean. This is illustrated by the EOF analysis of simulated precipitation in Fig. $4 \mathrm{~b}$ and $\mathrm{d}$.

The lower amplitude cooling during DO stadials weakens the trade winds by only $30 \%$. The corresponding southward shift of the tropical rainbands is less pronounced than for Heinrich stadials as shown by the leading principal component of the rainfall EOF analysis (Fig. 4d). In spite of a high correlation (0.92) between the principal components of temperature and rainfall, there are some notable differences. The precipitation mode exhibits a more pronounced two-step structure for the interstadial DO12 (around 47-46 ka) and a stronger difference between Heinrich stadials and DO stadials (Fig. 4d) than the temperature EOF mode (Fig. 4c). Qualitatively the patterns of simulated temperature and rainfall changes agree with those obtained from coupled general 

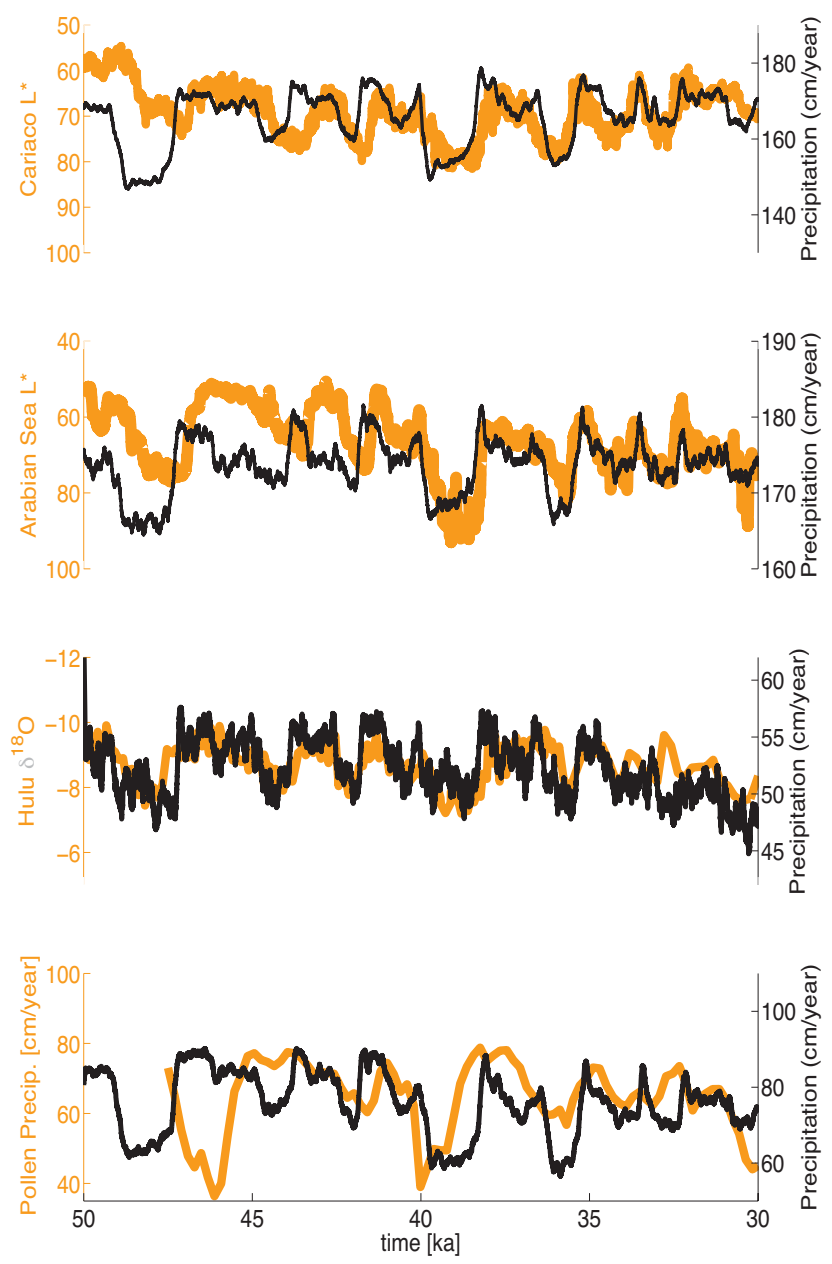

Fig. 5. From top to bottom: time series of simulated annual precipitation anomalies over the Cariaco Basin $\left(60-50^{\circ} \mathrm{W}, 5-20^{\circ} \mathrm{N}\right)$ compared to a reflectance record from the Cariaco Basin (Deplazes et al., 2013); time series of simulated Arabian Sea annual precipitation $\left(45-65^{\circ} \mathrm{E}, 5-15^{\circ} \mathrm{N}\right)$ compared to a reflectance record $\left(L^{*}\right)$ from the northeastern Arabian Sea (Deplazes et al., 2013); simulated precipitation in eastern China $\left(114-124^{\circ} \mathrm{E}, 28-35^{\circ} \mathrm{N}\right) \mathrm{com}-$ pared to a speleothem $\delta^{18} \mathrm{O}$ record (\%o) from Hulu Cave, China (Wang et al., 2001); time series of simulated Iberian region annual precipitation $\left(10-1^{\circ} \mathrm{W}, 35-40^{\circ} \mathrm{N}\right)$ compared to a composite of pollen-derived precipitation estimates from the Iberian margin and the Alboran Sea (Sánchez-Goñi et al., 2002); Model results are in black and paleoproxy records in orange.

circulation models subjected to North Atlantic freshwater perturbations (Broccoli et al., 2006; Timmermann et al., 2007; Kageyama et al., 2013).

Comparing the simulated northern hemispheric rainfall changes on a regional scale with hydroclimate reconstructions for the Mediterranean region (Sánchez-Goñi et al., 2002), the Cariaco Basin (Deplazes et al., 2013), the Arabian Sea (Deplazes et al., 2013), eastern China (Wang et al., 2001) (Fig. 5) and Central America (Hodell et al., 2008) (Fig. 6, upper panel), we find an excellent agreement between model

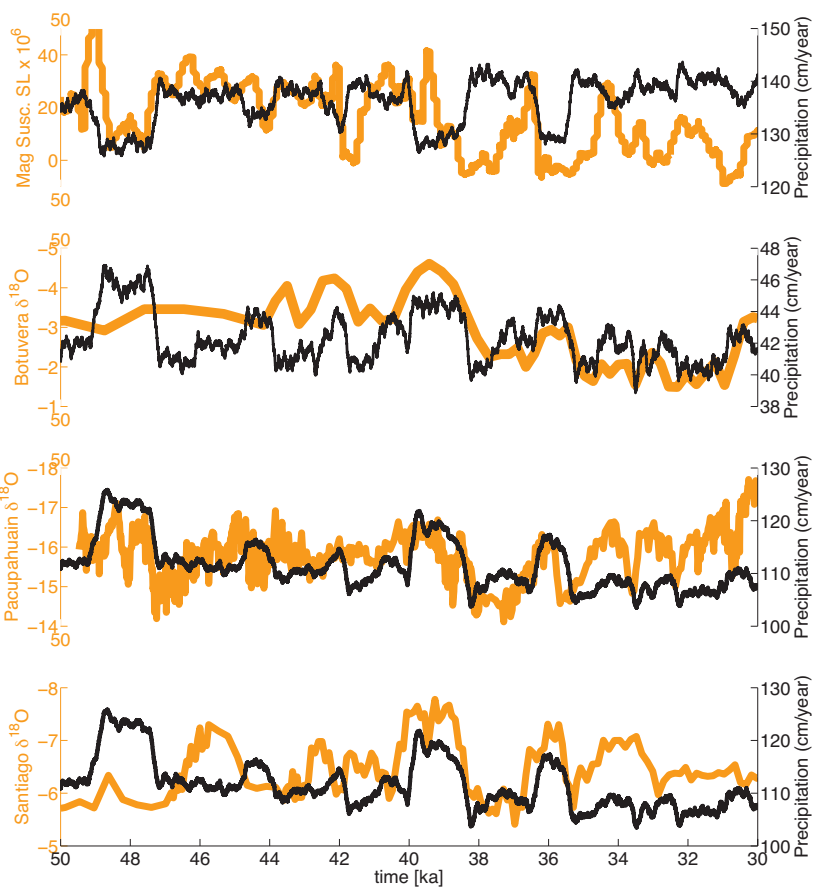

Fig. 6. From top to bottom: time series of simulated annual precipitation anomalies over Guatemala $\left(104-93^{\circ} \mathrm{W}, 12-30^{\circ} \mathrm{N}\right)$ compared to a magnetic susceptibility record from Lake Peten Itza, Guatemala (Hodell et al., 2008); Brazil (44-60 W, 20-30 S) compared to $\delta^{18} \mathrm{O}(\% \circ)$ of a speleothem record from Botuvera Cave, Brazil (Wang et al., 2007); Peru and Ecuador $\left(85-70^{\circ} \mathrm{W}, 3-15^{\circ} \mathrm{S}\right.$ ) compared to speleothems $\delta^{18} \mathrm{O}$ records from Pacupahuain Cave, Peru (Kanner et al., 2013) and Santiago Cave, Ecuador (Mosblech et al., 2012). Model results are in black and paleoproxy records in orange.

and data with stadial (interstadial) conditions corresponding to increased aridity (pluvials). While the pollen-derived precipitation estimate (Sánchez-Goñi et al., 2002) and the model output suggest much drier conditions over the Iberian region during HS5, the chronology of the proxy record is based on a graphic correlation with the GISP2 ice core, which places the HS5 much later than the new GICC05 chronology (Obrochta et al., 2014). It should be noted that reflectance and magnetic susceptibility are indirect hydroclimate proxies and thus cannot give quantitative estimates. In addition, speleothem $\delta^{18} \mathrm{O}$ can be potentially affected by other processes such as changes in temperature, soil evaporation and the water vapor sources. Age model uncertainties associated with the Arabian Sea record (Deplazes et al., 2013) could preclude any conclusions with respect to synchronicity with North Atlantic stadials. However, the high level of correspondence between our simulated precipitation changes and the Arabian Sea reflectance record indicates that North Atlantic stadials lead to drier synchronous conditions over the Arabian Sea. 

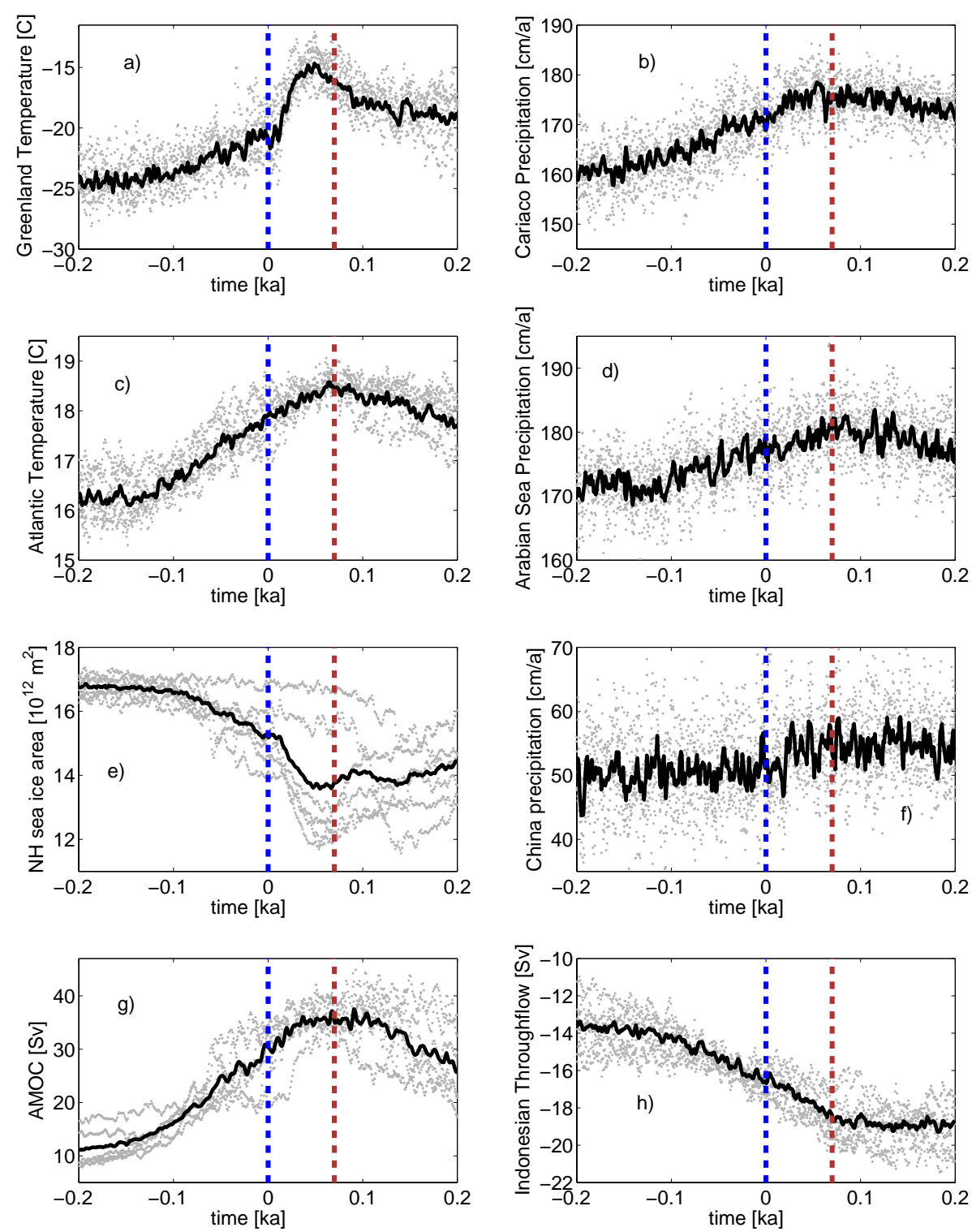

Fig. 7. Composite (thick black line) of DO stadial-interstadial transitions showing different simulated variables relative to the maximum time derivative in simulated Greenland temperatures occurring at 47.25, 43.9, 41.8, 38.3, 35.3, 33.6 and 32.34 ka BP: (a) Greenland air temperature, (b) Cariaco Basin precipitation, (c) North Atlantic temperature, (d) Arabian Sea precipitation, (e) northern hemispheric sea-ice area, (f) eastern China precipitation, (g) Maximum of meridional streamfunction in North Atlantic, (h) strength of Indonesian Throughflow. The blue and red dashed lines respectively represent the time of the largest positive time derivative of Greenland temperatures and the time when North Atlantic temperatures attain the maximum value. The gray dots represent the individual data points before calculating the composite.

The reverse pattern can be found for southern hemispheric hydroclimate proxies in Brazil (Wang et al., 2007), Peru (Kanner et al., 2013) and Ecuador (Mosblech et al., 2012) as well as for simulated rainfall changes (Fig. 6, lower three panels). In Sect. 3.6 we will try to reconcile some age-model discrepancies by projecting model and proxy data onto the common NGRIP GICC05 timescales (Andersen et al., 2006; Svensson et al., 2006).

\subsection{Abruptness of stadial-interstadial transitions}

To determine the response time of various climate variables and ocean transport indicators to freshwater changes, we calculate a composite (Fig. 7, black line) based on several stadial-interstadial DO transitions by aligning the model data relative to the maximum temperature derivative of the simulated Greenland temperature $(47.25,43.9,41.8,38.3,35.3$, 33.6, $32.34 \mathrm{kaBP})$. According to this analysis we find that 
the averaged DO transition takes place within 150 to $200 \mathrm{yr}$ for all the climate variables in Fig. 7. However, for Greenland temperatures (Fig. 7a) and northern hemispheric sea-ice area (Fig. 7e), we see a considerable acceleration and an associated increase of abruptness $100 \mathrm{yr}$ into the transition. This is in agreement with previous estimates of the abruptness of DO stadial-interstadial transitions in Greenland ice cores ( $\sim 125 \mathrm{yr}$ ) (Capron et al., 2010), although much higher rates were reported in atmospheric circulation proxies (Steffensen et al., 2008).

As already demonstrated in Figs. 3 and 5 rainfall changes in the Cariaco Basin area and the Arabian Sea clearly track millennial-scale SST variations in the North Atlantic region. This is further supported by the composite analysis which reveals a very similar time evolution of these variables for the averaged DO stadial-interstadial transition. Rainfall changes in eastern China are less well pronounced owing to a much larger level of simulated rainfall variability that is unrelated to DO cycles.

According to Fig. 7h, changes in the barotropic transport across the Indonesian archipelago occur almost in unison with the AMOC. This surprisingly fast adjustment can be attained by two processes: (i) wind changes in the Pacific (Timmermann et al., 2005b), and (ii) fast oceanic adjustment processes involving wave propagation from the Atlantic into the Indian and Pacific oceans, as discussed in Timmermann et al. (2005a). The former can modulate the Indonesian Throughflow via the island rule (Godfrey, 1989), whereas the latter would have to change the joint effect of baroclinicity and relief (JEBAR) term in the barotropic transport equation (Sarkisyan and Ivanov, 1971; Cane et al., 1998). Irrespective of the relative magnitudes of these terms, our analysis clearly documents that the DO variability has far-reaching fast oceanic impacts that extend also into the other ocean basins.

\subsection{Common age scale}

To better compare the paleorecords in Figs. 2, 3, 5 and the simulated climate variables, we make an attempt to bring the time series all onto the same age scale. We have chosen the Greenland Ice Core Chronology 2005 (GICC05) (Andersen et al., 2006; Svensson et al., 2006) as the common age model. To project the model simulation (30-50 ka BP) onto this age model, we compare the simulated Greenland temperature with the NGRIP $\delta^{18} \mathrm{O}$ (Svensson et al., 2006) and identify in a $1800 \mathrm{yr}$ sliding window the lag at which the lag correlation attains its maximum value. Here we allow maximum lags of $\pm 750 \mathrm{yr}$. To avoid large local discontinuities or reversals in the age model projection, we subsequently filtered the resulting time series of age adjustments for the model simulation using a $500 \mathrm{yr}$ running mean. The resulting Greenland temperature-based age shift is then applied to all other model variables, thus keeping, at least to first order, the leadlag structure within the model intact. We also project the

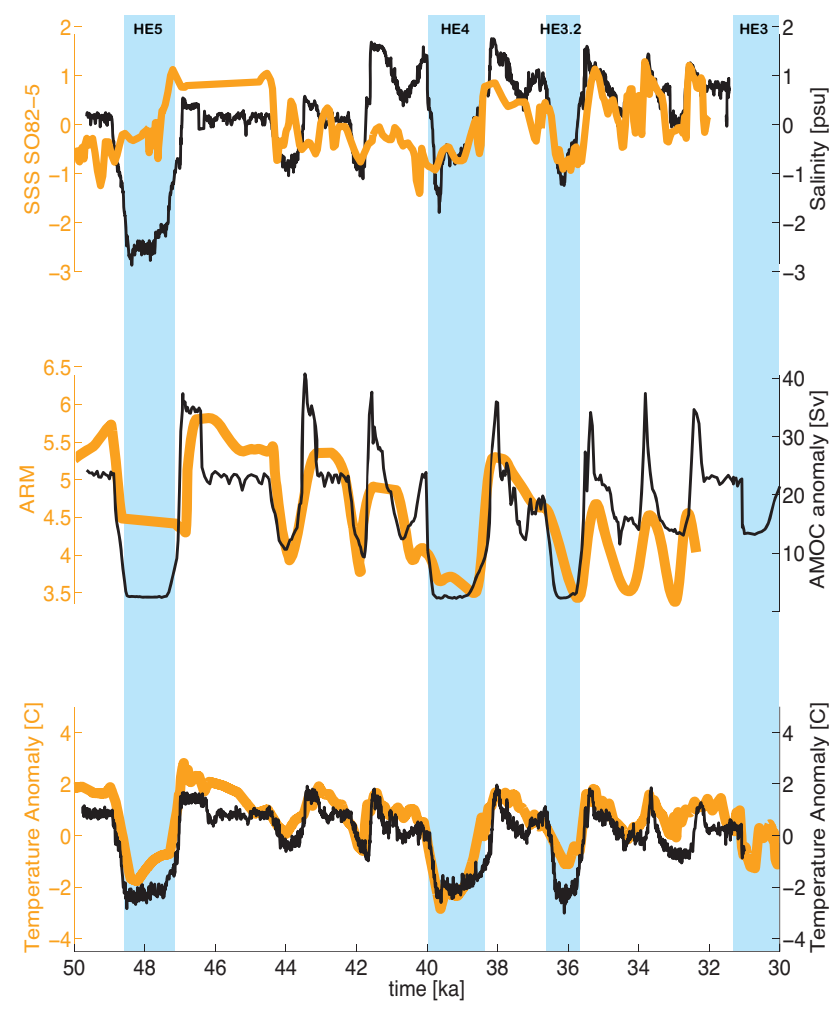

Fig. 8. From top to bottom: time series projected onto GICC05 age scale (Andersen et al., 2006; Svensson et al., 2006) of Nordic Seas salinity from core S082-5 (van Kreveld et al., 2000) and simulated surface salinity anomalies at this location; simulated maximum meridional overturning circulation in the North Atlantic (Sv) compared to North Atlantic marine sediment cores ARM data (Kissel et al., 2008); simulated SST anomalies off the Iberian margin (15$8^{\circ} \mathrm{W}, 37-43^{\circ} \mathrm{N}$ ) compared to alkenone-based SST anomalies from marine sediment core MD01-2444 (Martrat et al., 2007). Model results are in black and paleoproxy records in orange.

sea-surface salinity data from SO82-5 (van Kreveld et al., 2000), the ARM data and the Iberian margin SST (Fig. 8) as well as the Cariaco and Arabian seas color records (Fig. 9), onto the GICC05 timescale. Here we assume that at least in a $1800 \mathrm{yr}$ sliding window, the proxy data varies in synchrony with the Greenland temperature record at zero lag. This assumption is well justified by the model results that show maximum correlation of 0.92 between the principal components of the leading EOFs of temperature (Fig. 4a and c) and precipitation (Fig. 4b and d) at zero lag. Furthermore, our model-based composite analysis of DO stadial-interstadial transitions supports the notion of near synchronicity (within $\pm 100 \mathrm{yr}$ ) of the physical variables under consideration.

Having synchronized the model and paleoproxy data with the NGRIP $\delta^{18} \mathrm{O}$ record on GICC05, we find a much better agreement between model and paleoproxy records, particularly for the period $50-40 \mathrm{kaBP}$. The ARM data now nicely features marked AMOC weakening during HS5, HS4 and C7 as well as during most of the DO stadials (Fig. 8). In addition, 
Table 1. Table showing the timing of stadials HS5, HS4, C7/HS3.2 and HS3 as recorded in high-resolution well-dated paleorecords. We calculate the mean (ka BP) and one standard deviation (ka) of the timing of each stadial as well as the duration (yr) of each stadial and its standard deviation (yr). In the Pacupahuain record, the two peaks around HS5 were treated as a single event. A similar method was used for HS3 in the Hulu Cave record.

\begin{tabular}{|c|c|c|c|c|c|}
\hline Paleoproxy record & $\begin{array}{l}\text { HS5 } \\
\text { ka BP }\end{array}$ & $\begin{array}{l}\text { HS4 } \\
\text { ka BP }\end{array}$ & $\begin{array}{l}\mathrm{C} 7 / \mathrm{HS} 3.2 \\
\mathrm{ka} \mathrm{BP}\end{array}$ & $\begin{array}{l}\text { HS3 } \\
\text { ka BP }\end{array}$ & Ref. \\
\hline Greenland $\delta^{18} \mathrm{O}(\mathrm{GICC} 05)$ & $48.8-46.9$ & $39.95-38.25$ & $36.65-35.5$ & $32-28.9$ & Huber et al. (2006) \\
\hline Sofular Cave $\delta^{18} \mathrm{O}$ & $48.8-47.7$ & $39.9-38.2$ & $36.6-35.95$ & $31.5-29.5$ & Fleitmann et al. (2009) \\
\hline Pacupahuain Cave $\delta^{18} \mathrm{O}$ & $\begin{array}{l}48.7-48.2 \\
48.0-47.45\end{array}$ & $40.4-38.4$ & $36.4-35.8$ & $30.5-28.9$ & Kanner et al. (2013) \\
\hline Santiago Cave $\delta^{18} \mathrm{O}$ & $49-48.2$ & $40.1-38.6$ & $36.6-35.6$ & - & Mosblech et al. (2012) \\
\hline Hulu Cave $\delta^{18} \mathrm{O}$ & $48.8-47.6$ & $39.8-38.1$ & $36-35.2$ & $\begin{array}{l}31.3-29.8 \\
28.8-27.9\end{array}$ & Wang et al. (2001) \\
\hline Mean (ka BP) & $48.8-47.6$ & $40.0-38.3$ & $36.45-35.6$ & $31.3-28.8$ & \\
\hline Standard deviation (ka) & $0.1-0.5$ & $0.2-0.2$ & $0.2-0.3$ & $0.5-0.6$ & \\
\hline Duration (yr) & 1250 & 1720 & 840 & 1820 & \\
\hline Standard deviation (yr) & 360 & 160 & 210 & 730 & \\
\hline
\end{tabular}

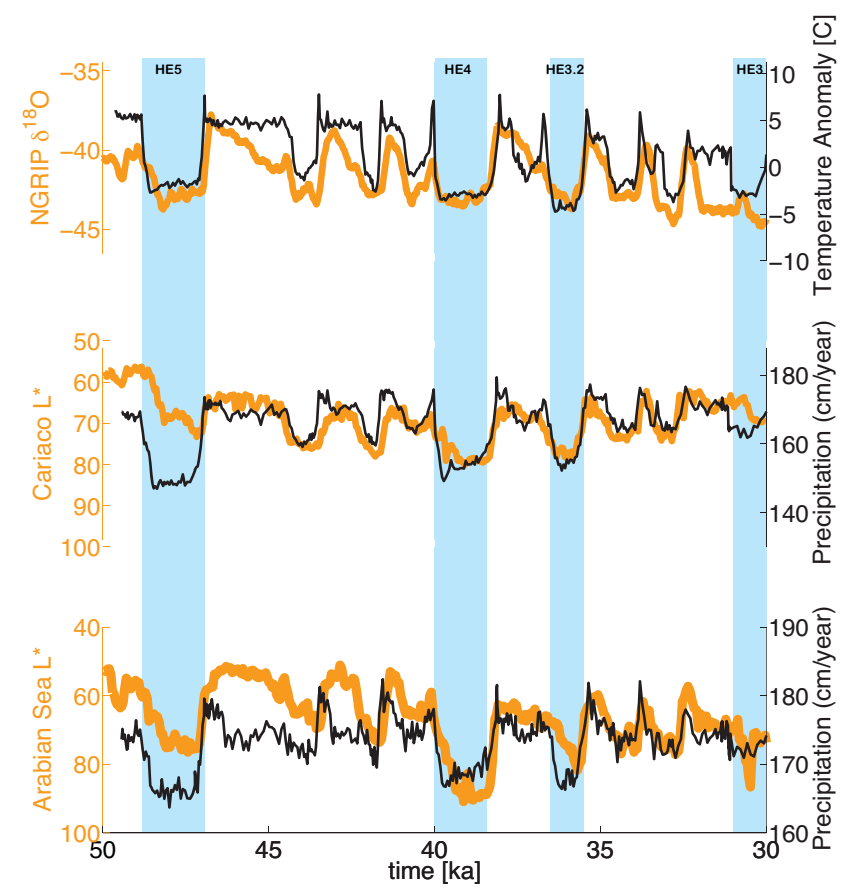

Fig. 9. From top to bottom: time series projected onto GICC05 age scale of simulated NE Greenland air temperature anomalies $\left(40^{\circ} \mathrm{W}-10^{\circ} \mathrm{E}, 66-85^{\circ} \mathrm{N}\right)$ and NGRIP $\delta^{18} \mathrm{O}$; simulated annual precipitation anomalies over the Cariaco Basin $\left(60-50^{\circ} \mathrm{W}, 5-20^{\circ} \mathrm{N}\right)$ compared to a reflectance record from the Cariaco Basin (Deplazes et al., 2013); time series of simulated Arabian Sea annual precipitation $\left(45-65^{\circ} \mathrm{E}, 5-15^{\circ} \mathrm{N}\right)$ compared to a reflectance record $\left(L^{*}\right)$ from the northeastern Arabian Sea (Deplazes et al., 2013). Model results are in black and paleoproxy records in orange. the precipitation records from the Cariaco Basin and the Arabian Sea are now in better agreement with the model, particularly for HS5 (Fig. 9).

We conclude that if forced with a freshwater forcing that leads to simulated salinity anomalies which closely resemble (within the dating uncertainties) paleosalinity reconstructions from the Nordic Seas (Fig. 8), the LOVECLIM model hindcast captures the dominant modes of Heinrich and DO variability found in paleoreconstructions. The model results further support that freshwater forcing triggered changes of the AMOC and North Atlantic SSTs, which subsequently caused the observed hydroclimate shifts across both Hemispheres. This confirms our initial hypothesis that ice-sheetdriven AMOC variations played a crucial role in generating the continuum of millennial-scale DO/Heinrich variability in the North Atlantic during MIS3 (see also Sarnthein et al., 2001). Potential feedbacks of AMOC variability on the mass balance of the major ice sheets will be discussed in Sect. 4 .

\subsection{Timing and duration of Heinrich stadials}

Here we will take the opportunity to revisit the timing of some important climate events during MIS3. We will focus in particular on Heinrich stadials (HS5, HS4 and HS3) and stadial C7 (see Fig. 1) and use high-resolution paleoclimate reconstructions with independent age control that capture Heinrich and DO variability. The timing from NGRIP on GICC05 (Andersen et al., 2006), Sofular Cave, Turkey (Fleitmann et al., 2009), Pacupahuain Cave, Peru (Kanner et al., 2013), Santiago Cave, Ecuador (Mosblech et al., 2012) and Hulu Cave (Wang et al., 2001) is summarized in Table 1. Results from Sect. 3.5 supports the notion of near synchronicity (within $\pm 100 \mathrm{yr}$ ) of the physical variables under consideration. Consolidated estimates for the timing of HS5, 


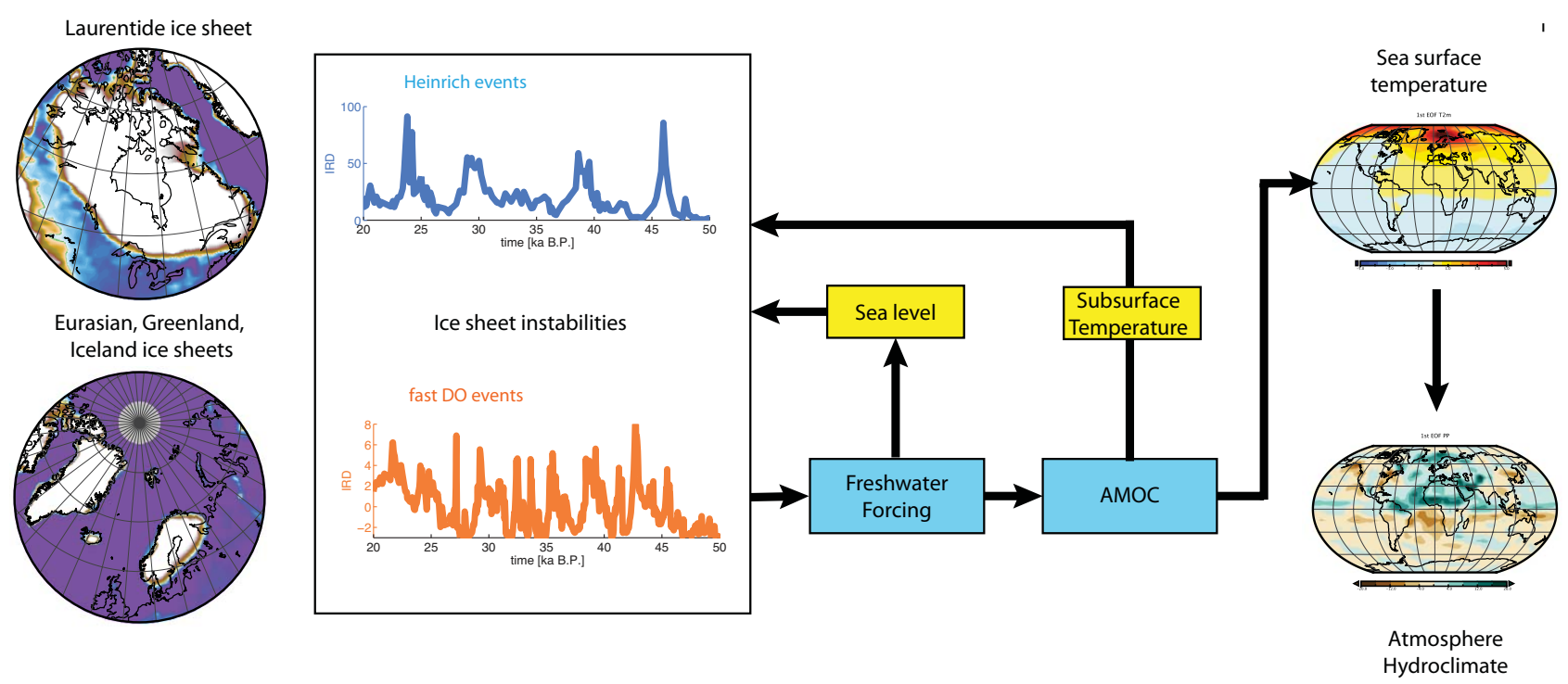

Fig. 10. Schematic illustration of the effect of northern hemispheric ice-sheet instabilities on the AMOC, SST and atmospheric circulation. AMOC changes are likely to provide a positive feedback on ice-sheet instabilities via subsurface temperature anomalies (Alvarez-Solas et al., 2010). Furthermore, sea level changes generated by one ice sheet can trigger ice-shelf instabilities in another ice sheet and subsequent accelerated flow and iceberg calving. Once the ice sheets reach a new mass balance, the freshwater input into the North Atlantic ceases and the AMOC starts its recovery thus initiating a stadial-interstadial DO transition.

HS4, C7 and HS3 are 48.8-47.6, 40.0-38.3, 36.45-35.6, and $31.3-28.8 \mathrm{kaBP}$, respectively, which agrees well with our model simulation (Figs. 2 and 3). These ranges also agree well with estimates from North Atlantic marine sediment cores for the timing of HS5 and HS4 (50-47 and 40.2-38.3 ka BP, respectively) (Sánchez-Goñi and Harrison, 2010).

The C7 stadial was accompanied by a considerable IRD pulse in the northeastern North Atlantic, as seen for instance in the sediment cores PS2644 (Voelker et al., 2000), SO825 (van Kreveld et al., 2000), JPC-13 (Hodell et al., 2010), MD95-2040 (Schönfeld et al., 2003), NA87-22 and SU 90-24 (Elliot et al., 2002). Furthermore, we find strongly reduced surface temperatures in the Atlantic and widespread northern hemispheric aridity (Figs. 2, 3 and 4). In our model simulation and in the paleoproxy data, the C7 stadial shares many common characteristics with the typical response for Heinrich stadials 3-5. In fact in the EOF analysis of the model simulation (Fig. 4), this period is basically indistinguishable from the other prominent Heinrich stadials, both in terms of temperature and rainfall. We therefore propose to introduce the term "Heinrich stadial 3.2" (HS3.2), using the same nomenclature introduced for Heinrich stadial 5.2 (Sarnthein et al., 2001).

Paleorecords as well as the model results display little coherency regarding the amplitude and the timing of HS3. It was suggested (Elliot et al., 1998; Scnoeckx et al., 1999; Grousset et al., 2000) that in contrast to other Heinrich events, HS3 may have originated from the Fennoscandian ice sheet. It is thus possible that iceberg discharges during
Heinrich event 3 had a different impact on the AMOC than for other Heinrich events.

\section{Conclusions}

Here we presented a new transient model simulation that covers the period 30-50 ka BP. This climate model hindcast experiment was designed in such a way that freshwater forcing between $55-10^{\circ} \mathrm{W}, 50-65^{\circ} \mathrm{N}$ generates AMOC changes and subsequently northeastern Atlantic temperature anomalies that are in agreement with alkenone-based temperature reconstructions from the Iberian margin area. With this weak constraint on model/data agreement, we were able to independently evaluate the model performance with numerous other high-resolution climate proxies from both hemispheres. A marked weakening of the AMOC reduces the oceanic and atmospheric poleward heat transport thus leading to a strong cooling over the North Atlantic region (Kageyama et al., 2013). In our model the cooling is centered on Scandinavia, extends over Greenland and northern Europe and is also simulated over southern Europe, North Africa and Asia. The cooling is the strongest at high latitudes due to sea-ice albedo feedbacks. Such temperature changes lead to a stronger surface temperature gradient over the North Atlantic and therefore to a strengthening of the North Easterly trades. The cooler conditions over the North Atlantic and stronger trades induce a southward shift of the ITCZ over the Atlantic region with drier conditions simulated over Europe, the northern part of South America, North Africa and the Middle East. 
The resulting high level of agreement between the model and paleoproxy records provides strong support for our initial hypothesis: namely that Heinrich and DO variability during MIS3 were caused by ice-sheet-driven changes in the strength of the AMOC. The relationship between stadials and IRD records from the North Atlantic region further indicates that northern hemispheric ice-sheet calving and freshwater discharges play a major role in disrupting the AMOC during MIS3 (Fig. 1). Figure 10 summarizes a scenario explaining DO/Heinrich variability, which follows some elements of Sarnthein et al. (2001). We suggest that ice-sheet instabilities of low amplitude, originating mostly from the Eurasian, Iceland and Greenland ice sheets (Bond and Lotti, 1995), are the main driver of the fast DO variability. The corresponding low amplitude freshwater flux perturbations triggered a weakening of the AMOC, but not a complete collapse. We further acknowledge the possibility that DO climate variability may have caused ice-sheet mass imbalances and calving from circum-Atlantic ice sheets (Bond and Lotti, 1995; Grousset et al., 2000, 2001; Marshall and Koutnik, 2006), thus contributing to the DO-synchronized delivery of IRD into the North Atlantic. In contrast, instabilities from the Laurentide ice sheet occurred less frequently but were associated with much larger iceberg and freshwater discharges, leading to complete AMOC shutdown and larger SST and hydroclimate changes in the North Atlantic realm and beyond. Changes in sea level during Heinrich events (Flückiger et al., 2006) and subsurface temperatures (Shaffer et al., 2004; Mignot et al., 2007; Alvarez-Solas et al., 2010; Marcott et al., 2011; Alvarez-Solas et al., 2013) (Fig. 10) may have subsequently triggered marine-ice-sheet instabilities, thus increasing the initial freshwater discharge. Such processes may have played a key role in synchronizing ice-sheet dynamics in the Northern Hemisphere and in prolonging ice-sheet instabilities during Heinrich events. Once the ice sheets reach a new mass balance, the freshwater input into the North Atlantic ceases, salinity increases rapidly to the more saline Arctic/North Atlantic glacial background state and the AMOC starts its recovery thus initiating a stadial-interstadial DO transition.

A more detailed view of the underlying mechanisms is provided in Fig. 11, which shows the time evolution of the composite IRD record (Fig. 1) from cores SO82-5 and PS2644 (orange, upper curve), the salinity reconstruction (blue, upper curve) from Irminger Sea core SO82-5 (van Kreveld et al., 2000), the North Atlantic ARM data (red, middle curve) (Kissel et al., 2008) as a proxy for changes in AMOC strength, summer SST variations from the Irminger Sea (cyan, middle curve) (van Kreveld et al., 2000) and the GISP2 ice-core temperature reconstruction (black, lower curve) (Alley, 2000). All data were interpolated onto the GICC05 timescales (see caption to Fig. 1 and Sect. 3.6 for more details). Here we begin with the high IRD values during HS4, low salinities and cold conditions in the Irminger Sea and a weak AMOC (40-39 ka BP). Around $\sim 39 \mathrm{kaBP}$ the strong freshwater forcing vanishes abruptly. Concomitantly,

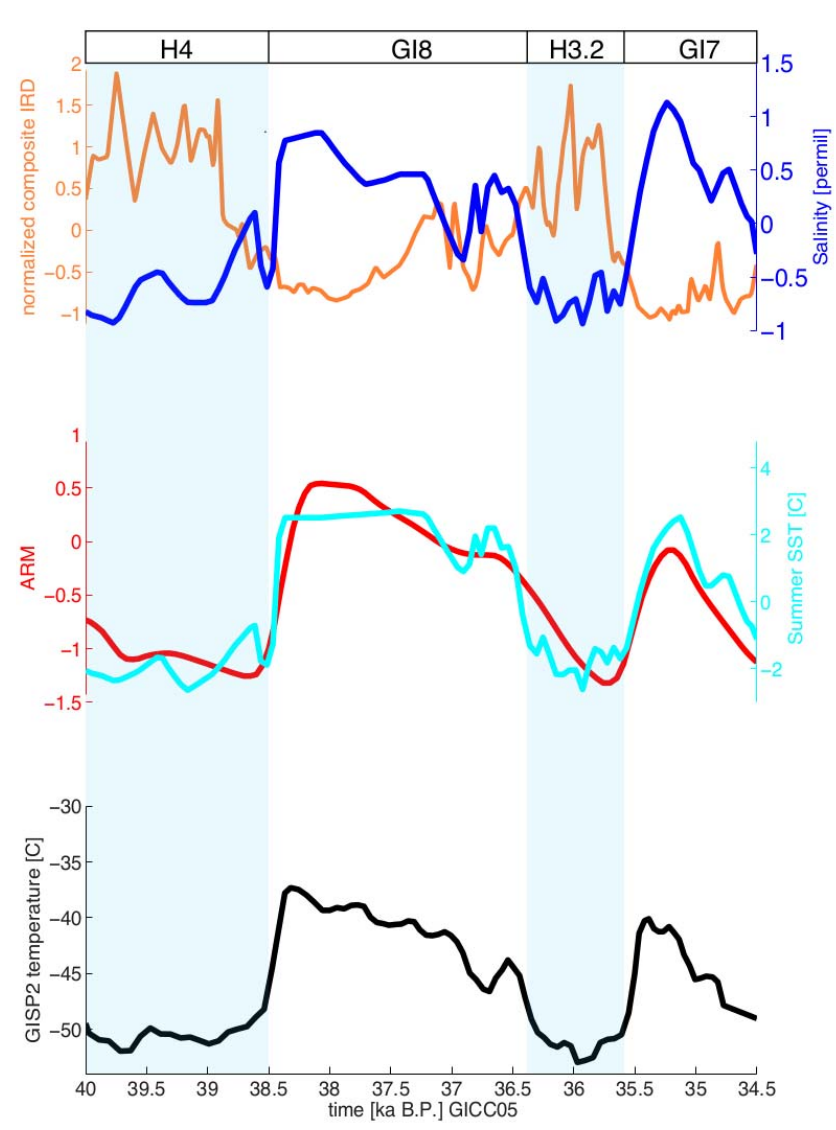

Fig. 11. Top panel: composite IRD record (orange) obtained from the average of the normalized northern North Atlantic IRD records SO82-5 (van Kreveld et al., 2000) and PS2644 (Voelker et al., 2000) (see Fig. 1) and Irminger Sea sea-surface salinities (blue) from SO82-5 (van Kreveld et al., 2000); middle panel: North Atlantic marine sediment cores ARM data (red) (Kissel et al., 2008) and Summer SST anomalies (cyan) from marine sediment core SO825 (van Kreveld et al., 2000); bottom panel: GISP2 reconstructed central Greenland temperatures (black) (Alley, 2000). All data are displayed on the GICC05 timescale (see Fig. 1).

sea-surface salinity increases thus initiating the AMOC recovery. The AMOC strengthening leads to Greenland and North Atlantic warming as well northern North Atlantic seaice retreat. Greenland interstadial 8 (GI8) is characterized by a very warm initial period which lasts for about 100 $200 \mathrm{yr}$ IRD is at its minimum, Nordic Seas surface salinity is high and so is the strength of the AMOC (Fig. 8). We consider this period of minimum ice-sheet calving a period of positive northern hemispheric ice-sheet mass balance (i.e. growth). Around $37.5 \mathrm{kaBP}$ calving resumes and increases until $37 \mathrm{kaBP}$. This evolution is briefly interrupted for about $100 \mathrm{yr}$ between 36.9-36.8 ka BP, before a period of rapid iceberg surging and an associated salinity decrease leads into the stadial cooling phase during HS3.2. The stadial iceberg surging period lasts for $1 \mathrm{ka}$ and comes to an end when the ice-sheet calving has exhausted itself. This is 
the initiation of GI7. The scenario outlined here for a set of paleoproxy data sets is entirely consistent with the modelingbased evidence from Figs. 8 and 9.

Our paper further highlights the different response characteristics of various climate variables to AMOC changes (Fig. 7). The extraordinary abruptness of Greenland temperature changes during the DO stadial-interstadial transition was identified as a regional phenomenon, which is likely induced by sea-ice feedbacks (Li et al., 2010; Deplazes et al., 2013). Given the fact that the North Atlantic temperature and AMOC composite shown in Fig. 7 have already reached 2/3 of their full DO amplitude at zero lag whereas Greenland temperatures have only attained about $50 \%$, it may appear as if the Greenland record is lagging the other variables. This is merely a reflection of the nonlinearity of the Greenland temperature response. It should be noted here that this feature may impact the synchronization of high-resolution proxy time series with Greenland climate reconstructions.

According to our model and data-based evidence, we conclude that ice-sheet/freshwater-driven AMOC variations and local feedbacks determined the timing and abruptness of DO events as well as their global teleconnections.

Acknowledgements. This project was supported by the Australian Research Council. Model experiments were performed on a computational cluster owned by the Faculty of Science of the University of New South Wales as well as on a cluster from the NCI National Facility at the Australian National University. T. Friedrich and A. Timmermann are supported by NSF grant no. 1010869 and by the Japan Agency for Marine-Earth Science and Technology (JAMSTEC) through its sponsorship of the International Pacific Research Center. M. England acknowledges funding from the ARC Laureate Fellowship program (FL100100214). We thank C. Jackson for providing his optimized freshwater forcing time series as well as M. Elliot and N. Thouveny for providing their data for comparisons. We are also grateful to S. Harrison for organizing a workshop at Macquarie University, that stimulated many interesting discussions on DO events and to M. Sarnthein for insightful discussions.

Edited by: D. Fleitmann

\section{References}

Abe-Ouchi, A., Segawa, T., and Saito, F.: Climatic Conditions for modelling the Northern Hemisphere ice sheets throughout the ice age cycle, Clim. Past, 3, 423-438, doi:10.5194/cp-3-423-2007, 2007.

Alley, R.: Ice-core evidence of abrupt climate changes, P. Natl. Acad. Sci. USA, 97, 1331-1334, 2000.

Alvarez-Solas, J., Charbit, S., Ritz, C., Paillard, D., Ramstein, G., and Dumas, C.: Links between ocean temperature and iceberg discharge during Heinrich events, Nat. Geosci., 3, 122-126, doi:10.1038/NGEO752, 2010.
Alvarez-Solas, J., Robinson, A., Montoya, M., and Ritz, C.: Iceberg discharges of the last glacial period driven by oceanic circulation changes, P. Natl. Acad. Sci., 110, 16350-16354, doi:10.1073/pnas.1306622110, 2013.

Andersen, K., Svensson, A., Johnsen, S., Rasmussen, S., Bigler, M., Röthlisberger, R., Ruth, U., Siggaard-Andersen, M.-L., Steffensen, J., Dahl-Jensen, D., Vinther, B., and Clausen, H.: The Greenland Ice Core Chronology 2005, 15-42 ka, Part 1: Constructing the time scale, Quaternary Sci. Rev., 25, 3246-3257, 2006.

Barker, S., Diz, P., Vautravers, M., Pike, J., Knorr, G., Hall, I., and Broecker, W.: Interhemispheric Atlantic seesaw response during the last deglaciation, Nature, 457, 1097-1102, 2009.

Blunier, T., Chappellaz, J., Schwander, J., Dällenbach, A., Stauffer, B., Stocker, T., Raynaud, D., Jouzel, J., Clausens, H., Hammer, C., and Johnsen, S.: Asynchrony of Antarctic and Greenland climate change during the last glacial period, Nature, 394, 739-743, 1998.

Bond, G. and Lotti, R.: Iceberg discharges into the North Atlantic on millennial time scales during the last glaciation, Science, 267, 1005-1010, 1995.

Braun, H., Ditlevsen, P., and Chialvo, D. R.: Solar forced Dansgaard-Oeschger events and their phase relation with solar proxies, Geophys. Res. Lett, 35, L06703, doi:10.1029/2008GL033414, 2008.

Broccoli, A., Dahl, K., and Stouffer, R.: Response of the ITCZ to Northern hemisphere cooling, Geophys. Res. Lett., 33, L01702, doi:10.1029/2005GL024546, 2006.

Brovkin, V., Ganopolski, A., and Svirezhev, Y.: A continuous climate-vegetation classification for use in climate-biosphere studies, Ecol. Model., 101, 251-261, 1997.

Cane, M. A., Kamenkovich, V. M., and Krupitsky, A.: On the Utility and Disutility of JEBAR, J. Phys. Oceanogr., 28, 519-526, 1998.

Capron, E., Landais, A., Chappellaz, J., Schilt, A., Buiron, D., Dahl-Jensen, D., Johnsen, S. J., Jouzel, J., Lemieux-Dudon, B., Loulergue, L., Leuenberger, M., Masson-Delmotte, V., Meyer, H., Oerter, H., and Stenni, B.: Millennial and sub-millennial scale climatic variations recorded in polar ice cores over the last glacial period, Clim. Past, 6, 345-365, doi:10.5194/cp-6-3452010, 2010.

Chapman, M. and Shackleton, N.: Global ice-volume fluctuations, North Atlantic ice-rafting events, and deep-ocean circulation changes between 130 and $70 \mathrm{ka}$, Geology, 27, 795-98, doi:10.1130/0091-7613, 1999.

Dansgaard, W., Johnsen, S., and Clausen, H.: Evidence for general instability of past climate from a 250-kyr ice-core record, Nature, 364, 218-220, 1993.

Deplazes, G., Lückge, A., Peterson, L., Timmermann, A., Hamann, Y., Hughen, K., Röh, U., Laj, C., Cane, M., Sigman, D., and Haug, G.: Links between tropical rainfall and North Atlantic climate during the last glacial period, Nat. Geosci., 6, 213-217, 2013.

Dokken, T., Nisancioglu, K., Li, C., Battisti, D., and Kissel, C.: Dansgaard-Oeschger cycles: Interactions between ocean and sea ice intrinsic to the Nordic seas, Paleoceanography, 28, 491-502, 2013. 
Elliot, M., Labeyrie, L., Bond, G., Cortijo, E., Turon, J.-L., Tisnerat, N., and Duplessy, J.-C.: Millennial-scale iceberg discharges in the Irminger Basin during the last glacial period: Relationship with the Heinrich events and the environmental settings, Paleoceanography, 13, 433-446, 1998.

Elliot, M., Labeyrie, L., and Duplessy, J.-C.: Changes in North Atlantic deep-water formation associated with the DansgaardOeschger temperature oscillations (60-10 ka), Quaternary Sci. Rev., 21, 1153-1165, 2002.

Fleitmann, D., Cheng, H., Badertscher, S., Edwards, R., Mudelsee, M., Göktürk, O., Fankhauser, A., Pickering, R., Raible, C., Matter, A., Kramers, J., and Tüysüz, O.: Timing and climatic impact of Greenland interstadials recorded in stalagmites from northern Turkey, Geophys. Res. Lett., 36, L19707, doi:10.1029/2009GL040050, 2009.

Flückiger, J., Knutti, R., and White, J.: Oceanic processes as potential trigger and amplifying mechanisms for Heinrich events, Paleoceanography, 21, PA2014, doi:10.1029/2005PA001204, 2006.

Garcin, Y., Williamson, D., Taieb, M., Vincens, A., Mathé P.-E., and Majule, A.: Centennial to millennial changes in maar-lake deposition during the last 45,000 years in tropical Southern Africa (Lake Masoko, Tanzania), Palaeogeogr. Palaeocl., 239, 334-354, 2006.

Godfrey, J.: A Sverdrup model of the depth-integrated flow from the world ocean allowing for island circulations, Geophys. Astrophys. Fluid Dyn., 45, 89-112, 1989.

Goosse, H., Brovkin, V., Fichefet, T., Haarsma, R., Huybrechts, P., Jongma, J., Mouchet, A., Selten, F., Barriat, P.-Y., Campin, J.M., Deleersnijder, E., Driesschaert, E., Goelzer, H., Janssens, I., Loutre, M.-F., Morales Maqueda, M. A., Opsteegh, T., Mathieu, P.-P., Munhoven, G., Pettersson, E. J., Renssen, H., Roche, D. M., Schaeffer, M., Tartinville, B., Timmermann, A., and Weber, S. L.: Description of the Earth system model of intermediate complexity LOVECLIM version 1.2, Geosci. Model Dev., 3, 603-633, doi:10.5194/gmd-3-603-2010, 2010.

Grousset, F., Labeyrie, L., Sinko, J., Cremer, M., Bond, G., Duprat, J., Cortija, E., and Huon, S.: Patterns of Ice-Rafted Detritus in the Glacial North Atlantic (40-55 N), Paleoceanography, 8, 175192, 1993.

Grousset, F., Pujol, C., Labeyrie, L., Auffret, G., and Boelaert, A.: Were the North Atlantic Heinrich events triggered by the behavior of the European ice sheets?, Geology, 28, 123-126, 2000.

Grousset, F., Cortijo, E., Huon, S., Hervé, L., Richter, T., Burdloff, D., Duprat, J., and Weber, O.: Zooming in on Heinrich layers, Paleoceanography, 16, 240-259, 2001.

Harrison, S. and Sánchez-Goñi, M.: Global patterns of vegetation response to millennial-scale variability and rapid climate change during the last glacial period, Quaternary Sci. Rev., 29, 29572980, 2010.

Heinrich, H.: Origin and consequences of cyclic ice rafting in the northeast Atlantic Ocean during the past 130,000 years, Quatern. Res., 29, 142-152, 1988.

Hemming, S.: Heinrich events: Massive late Pleistocene detritus layers of the North Atlantic and their global climate imprint, Rev. Geophys., 42, RG1005, doi:10.1029/2003RG000128, 2004.
Hodell, D., Anselmetti, F., Ariztegui, D., Brenner, M., Curtis, J., Gilli, A., Grzesik, D., Guilderson, T., Müller, A., Bush, M., Correa-Metrio, A., Escobar, J., and Kutterolf, S.: An 85-ka record of climate change in lowland Central America, Quaternary Sci. Rev., 27, 1152-1165, 2008.

Hodell, D., Evans, H., Channell, J., and Curtis, J.: Phase relationships of North Atlantic ice-rafted debris and surface-deep climate proxies during the last glacial period, Quaternary Sci. Rev., 29, 3875-3886, 2010.

Huber, C., Leuenberger, M., Spahni, R., Flückiger, J., Schwander, J., Stocker, T., Johnsen, S., Landais, A., and Jouzel, J.: Isotope calibrated Greenland temperature record over Marine Isotope Stage 3 and its relation to $\mathrm{CH}_{4}$, Earth Planet. Sc. Lett., 243, 504 519, 2006.

Jackson, C. S., Marchal, O., Liu, Y., Lu, S., and Thompson, W. G.: A box-model test of the freshwater forcing hypothesis of abrupt climate change and the physics governing ocean stability, Paleoceanography, 25, PA4222, doi:10.1029/2010PA001936, 2010.

Kageyama, M., Merkel, U., Otto-Bliesner, B., Prange, M., AbeOuchi, A., Lohmann, G., Ohgaito, R., Roche, D. M., Singarayer, J., Swingedouw, D., and Zhang, X.: Climatic impacts of fresh water hosing under Last Glacial Maximum conditions: a multimodel study, Clim. Past, 9, 935-953, doi:10.5194/cp-9-9352013, 2013.

Kanner, L., Burns, S., Cheng, H., and Edwards, R. L.: High-Latitude Forcing of the South American Summer Monsoon During the Last Glacial, Science, 335, 570-573, 2013.

Kissel, C., Laj, C., Piotrowski, A., Goldstein, S., and Hemming, S.: Millennial-scale propagation of Atlantic deep waters to the glacial Southern Ocean, Paleoceanography, 23, PA2102, doi:10.1029/2008PA001624, 2008.

Krebs, U. and Timmermann, A.: Tropical air-sea interactions accelerate the recovery of the Atlantic Meridional Overturning Circulation after a major shutdown, J. Climate, 20, 4940-4956, 2007.

Li, C., Battisti, D., Schrag, D., and Tziperman, E.: Abrupt climate shifts in Greenland due to displacements of the sea ice edge, Geophys. Res. Lett., 32, L19702, doi:10.1029/2005GL023492, 2005.

Li, C., Battisti, D., and Bitz, C.: Can North Atlantic Sea Ice Anomalies Account for Dansgaard-Oeschger Climate Signals?, J. Climate, 23, 5457-5475, 2010.

Marcott, S., Clark, P., Padman, L., Klinkhammer, G., Springer, S., Liu, Z., Otto-Bliesner, B., Carlson, A., Ungerer, A., Padman, J., He, F., Cheng, J., and Schmittner, A.: Ice-shelf collapse from subsurface warming as trigger for Heinrich events, P. Natl. Acad. Sci., 108, 13415-13419, doi:10.1073/pnas.1104772108, 2011.

Margari, V., Skinner, L. C., Tzedakis, P. C., Ganopolski, A., Vautravers, M., and Shackleton, N. J.: The nature of millennialscale climate variability during the past two glacial periods, Nat. Geosci., 3, 127-131, 2010.

Marshall, S. J. and Koutnik, M.: Ice sheet action versus reaction: Distinguishing between Heinrich events and DansgaardOeschger cycles in the North Atlantic, Paleoceanography, 21, PA2021, doi:10.1029/2005PA001247, 2006.

Martrat, B., Grimalt, J., Shackleton, N., de Abreu, L., Hutterli, M., and Stocker, T.: Four climate cycles of recurring deep and surface water destabilizations on the Iberian margin, Science, 317, 502507, 2007. 
Masson-Delmotte, V., Schulz, M., Abe-Ouchi, A., Beer, J., Ganopolski, A., Rouco, J. F. G., Jansen, E., Lambeck, K., Luterbacher, J., Naish, T., Osborn, T., Otto-Bliesner, B., Quinn, T., Ramesh, R., Rojas, M., Shao, X., and Timmermann, A.: Climate Change 2013: The Physical Science Basis. Contribution of Working Group I to the Fifth Assessment Report of the Intergovernmental Panel on Climate Change, in: Information from Paleoclimate Archives, Cambridge Univ. Press., Cambridge, UK and New York, NY, USA, 2013.

Menviel, L., Timmermann, A., Mouchet, A., and Timm, O.: Meridional reorganizations of marine and terrestrial productivity during Heinrich events, Paleoceanography, 23, PA1203, doi:10.1029/2007PA001445, 2008.

Mignot, J., Ganopolski, A., and Levermann, A.: Atlantic subsurface temperatures: Response to a shutdown of the overturning circulation and consequences for its recovery, J. Climate, 20, 48844898, 2007.

Mosblech, N., Bush, M., Gosling, W., Hodell, D., Thomas, L., van Calsteren, P., Correa-Metrio, A., Valencia, B., Curtis, J., and vanWoesik, R.: North Atlantic forcing of Amazonian precipitation during the last ice age, Nat. Geosci., 5, 817-820, doi:10.1038/NGEO1588, 2012.

Mouchet, A.: A 3D model of ocean biogeochemical cycles and climate sensitivity studies, Ph.D. thesis, Université de Liège, Lìege, Belgium, 2011.

Nave, S., Labeyrie, L., Gherardi, J., Caillon, N., Cortija, E., Kissel, C., and Abrantes, F.: Primary productivty response to Heinrich events in the North Atlantic Ocean and Norwegian Sea, Paleoceanography, 22, PA3216, doi:10.1029/2006PA001335, 2007.

Obrochta, S., Yokohama, Y., Moren, J., and Crowley, T.: Conversion of GISP2-based sediment core age models to the GICC05 extended chronology, Quatern. Geochronol., 20, 1-7, doi:10.1016/j.quageo.2013.09.001, 2014.

Petersen, S., Schrag, D., and Clark, P.: A new mechanism for Dansgaard-Oeschger cycles, Paleoceanography, 28, 1-7, doi:10.1029/2012PA002364, 2013.

Rashid, H., Hesse, R., and Piper, D.: Evidence for an additional Heinrich event between H5 and H6 in the Labrador Sea, Paleoceanography, 18, 1077, doi:10.1029/2003PA000913, 2003.

Sánchez-Goñi, M. and Harrison, S.: Millennial-scale climate variability and vegetation changes during the Last Glacial: Concepts and terminology, Quaternary Sci. Rev., 29, 2823-2827, 2010.

Sánchez-Goñi, M., Cacho, I., Turon, J.-L., Guiot, J., Sierro, F., Peypouquet, J.-P., Grimalt, J., and Shackleton, N.: Synchroneity between marine and terrestrial responses to millennial scale climatic variability during the last glacial period in the Mediterranean region, Clim. Dynam., 19, 95-105, 2002.

Sarkisyan, A. and Ivanov, V. F.: Joint effect of baroclinicity and bottom relief as an important factor in the dynamics of sea currents, Izv. Acad. Sci. USSR, Atmos. Ocean. Phys., 7, 116-124, 1971.

Sarnthein, M., Eystein, J., Weinelt, M., Arnold, M., Duplessy, J., Erlenkeuser, H., Flatoy, A., Johannessen, G., Johannessen, T., Jung, S., Koc, N., Labeyrie, L., Maslin, M., Pflaumann, U., and Schulz, H.: Variations in Atlantic surface ocean paleoceanography, $50-80^{\circ} \mathrm{N}$ : A time-slice record of the last 30,000 years, Paleoceanography, 10, 1063-1094, 1995.
Sarnthein, M., Stattegger, K., Dreger, D., Erlenkeuser, H., Grootes, P., Haupt, B., Jung, S., Kiefer, T., ad U. Pflaumann, W. K., Schäfer-Neth, C., Schulz, H., Schulz, M., Seidov, D., Simstich, J., van Kreveld, S., Vogelsang, E., Völker, A., and Weinelt, M.: The Northern North Atlantic: A Changing Environment, in: Fundamental Modes and Abrupt Changes in North Atlantic Circulation and Climate over the last $60 \mathrm{ky}$ - Concepts, Reconstruction and Numerical Modeling, Springer, Berlin, 365-410, 2001.

Schönfeld, J., Zahn, R., and de Abreu, L.: Surface to deep water response to rapid climate changes at the Western Iberian Margin, Global Planet. Change, 36, 237-264, 2003.

Schulz, M., Paul, A., and Timmermann, A.: Relaxation oscillators in concert: A framework for climate change at millennial timescales during the late Pleistocene, Geophys. Res. Lett., 29, 2193, doi:10.1029/2002GL016144, 2002.

Scnoeckx, H., Grousset, F., Revel, M., and Boelaert, A.: European contribution of ice-rafted sand to Heinrich layers H3 and H4, Mar. Geol., 158, 197-208, 1999.

Shaffer, G., Olsen, S., and Bjerrum, C.: Ocean subsurface warming as a mechanism for coupling Dansgaard-Oeschger climate cycles and ice-rafting events, Geophys. Res. Lett., 31, L24202, doi:10.1029/2004GL020968, 2004.

Siddall, M., Rohling, E., Almogi-Labin, A., Hemleben, C., Meischner, D., Schmelzer, I., and Smeed, D.: Sea-level fluctuations during the last glacial cycle, Nature, 423, 853-858, 2003.

Steffensen, J., Andersen, K., Bigler, M., Clausen, H., Dahl-Jensen, D., Fischer, H., Goto-Azuma, K., Hansson, M., Johnsen, S., Jouzel, J., Masson-Delmotte, V., Popp, T., Rasmussen, S., Röthlisberger, R., Ruth, U., Stauffer, B., Siggaard-Andersen, M.L., Sveinbjörnsdóttir, A., Svensson, A., and White, J.: HighResolution Greenland Ice Core Data Show Abrupt Climate Change Happens in Few Years, Science, 321, 680-684, 2008.

Stenni, B., Buiron, D., Frezzotti, M., Albani, S., Barbante, C., Bard, E., Barnola, J., Baroni, M., Baumgartner, M., Bonazza, M., Capron, E., Castellano, E., Chappellaz, J., Delmonte, B., Falourd, S., Genoni, L., Iacumin, P., Jouzel, J., Kipfstuhl, S., Landais, A., Lemieux-Dudon, B., Maggi, V., Masson-Delmotte, V., Mazzola, C., Minster, B., Montagnat, M., Mulvaney, R., Narcisi, B., Oerter, H., Parrenin, F., Petit, J., Ritz, C., Scarchilli, C., Schilt, A., Schüpbach, S., Schwander, J., Selmo, E., Severi, M., Stocker, T., and Udisti, R.: Expression of the bipolar see-saw in Antarctic climate records during the last deglaciation, Nat. Geosci., 4, 46-49, 2011.

Stocker, T.: The seesaw effect, Science, 282, 61-62, 1998.

Stocker, T. and Johnsen, S.: A minimum thermodynamic model for the bipolar seesaw, Paleoceanography, 18, 1087, doi:10.1029/2003PA000920, 2003.

Stouffer, R., Yin, J., Gregory, J., Dixon, K., Spelman, M., Hurlin, W., Weaver, A., Eby, M., Flato, G., Hasumi, H., Hu, A., Jungclaus, J., Kamenkovich, I., Levermann, A., Montoya, M., Murakami, S., Nawrath, S., Oka, A., Peltier, W., Robitaille, D., Sokolov, A., Vettoretti, G., and Weber, S.: Investigating the causes of the response of the thermohaline circulation to past and future climate changes, J. Climate, 19, 1365-1387, 2006.

Stouffer, R., Seidov, D., and Haupt, B.: Climate response to external sources of freshwater: North Atlantic versus the Southern Ocean, J. Climate, 20, 436-448, 2007. 
Svensson, A., Andersen, K., Bigler, M., Clausen, H., Dahl-Jensen, S. D., Johnsen, S., Muscheler, R., Rasmussen, S., Röthlisberger, R., Steffensen, J., and Vinther, B.: The Greenland Ice Core Chronology 2005, 15-42 ka, Part 2: Comparison to other records, Quaternary Sci. Rev., 25, 3258-3267, 2006.

Timm, O. and Timmermann, A.: Simulation of the last 21,000 years using accelerated transient boundary conditions, J. Climate, 20, 4377-4401, 2007.

Timm, O., Timmermann, A., Abe-Ouchi, A., and Segawa, T.: On the definition of paleo-seasons in transient climate simulations, Paleoceanography, 23, PA2221, doi:10.1029/2007PA001461, 2008.

Timmermann, A., Schulz, M., Gildor, H., and Tziperman, E.: Coherent resonant millennial-scale climate oscillations triggered by massive meltwater pulses, J. Climate, 16, 2569-2585, 2003.

Timmermann, A., An, S. I., Krebs, U., and Goosse, H.: ENSO suppression due to a weakening of the North Atlantic thermohaline circulation, J. Climate, 18, 3122-3139, 2005a.

Timmermann, A., Krebs, U., Justino, F., Goosse, H., and Ivanochko, T.: Mechanisms for millennial-scale global synchronization during the last glacial period, Paleoceanography, 20, PA4008, doi:10.1029/2004PA001090, 2005b.

Timmermann, A., Okumura, Y., An, S.-I., Clement, A., Dong, B., Guilyardi, E., Hu, A., Jungclaus, J., Krebs, U., Renold, M., Stocker, T., Stouffer, R., Sutton, R., Xie, S.-P., and Yin, J.: The influence of shutdown of the Atlantic meridional overturning circulation on ENSO, J. Climate, 19, 4899-4919, 2007.

Timmermann, A., Menviel, L., Okumura, Y., Schilla, A., Merkel, U., Hu, A., Otto-Bliesner, B., and Schulz, M.: Towards a quantitative understanding of millennial-scale Antarctic Warming events, Quaternary Sci. Rev., 29, 74-85, doi:10.1016/j.quascirev.2009.06.021, 2009a.
Timmermann, A., Timm, O., Stott, L., and Menviel, L.: The roles of $\mathrm{CO}_{2}$ and orbital forcing in driving southern hemispheric temperature variations during the last $21000 \mathrm{yr}$, J. Climate, 22, 16261640, 2009b.

van Kreveld, S., Samthein, M., Erlenkeuser, H., Grootes, P., Jung, S., Nadeau, M., Pflaumann, U., and Voelker, A.: Potential links between surging ice sheets, circulation changes, and the Dansgaard-Oeschger cycles in the Irminger Sea, 60-18 kyr, Paleoceanography, 15, 425-442, 2000.

Vidal, L., Labeyrie, L., Cortijo, E., Arnold, M., Duplessy, J., Michel, E., Becque, S., and van Weering, T.: Evidence for changes in the North Atlantic Deep Water linked to meltwater surges during the Heinrich events, Earth Planet. Sc. Lett., 146, 13-27, 1997.

Voelker, A., Grootes, P. M., Nadeau, M.-J., and Sarnthein, M.: Radiocarbon levels in the Iceland sea from $25-53 \mathrm{kyr}$ and their link to the Earth's magnetic field intensity, Radiocarbon, 42, 437452, 2000.

Wang, X., Auler, A., Edwards, R., Cheng, H., Ito, E., Wang, Y., Kong, X., and Solheid, M.: Millennial-scale precipitation changes in southern Brazil over the past 90,000 years, Geophys. Res. Lett., 34, L23701, doi:10.1029/2007GL031149, 2007.

Wang, Y., Cheng, H., Edwards, R., An, Z., Wu, J., Shen, C., and Dorale, J.: A high-resolution absolute-dated Late Pleistocene monsoon record from Hulu Cave, China, Science, 294, 2345-2348, 2001.

Zahn, R., Schönfeld, J., Kudrass, H.-R., Park, M.-H., Erlenkeuser, H., and Grootes, P.: Thermohaline instability in the North Atlantic during meltwater events: Stable isotope and ice-rafted detritus records from core SO75-26KL, Portuguese margin, Paleoceanography, 12, 696-710, 1997. 